\title{
Warunki i sens praktyki demokratycznej w XX wieku
}

\section{Wstęp}

Historia jest procesem ciągłym, ale jest też dzielona na etapy o charakterystycznych cechach. Niedawno skończony XX wiek, określany często wiekiem totalitaryzmu, charakteryzował się też sporami ideologicznymi oraz praktyką demokratyczna, która wynikała z doświadczeń wcześniejszych. Wiek ten poprzedzały triumfalny pochód filozofii Oświecenia, krytyka kapitalizmu i debaty na temat socjalizmu zapoczątkowane w XIX wieku. „Dyskusja nad społecznymi przesłankami egalitaryzmu prowadziła również do refleksji antydemokratycznej. Przyznanie równych praw nierówno obdarzonym przez naturę jednostkom stwarzało ryzyko, że $\mathrm{w}$ istocie mechanizmami demokratycznymi będą kierować nieliczni. Obserwacja ta inspirowała próbę zbadania, »kto faktycznie rządzi demokracjąu. Rozważania nad »pozornością władzy ludu« otwierały drogę do rozwoju koncepcji »faktycznej« władzy elit, rządów wybranych jednostek, ras, biurokratów, technokratów, menedżerów, związków zawodowych, partii politycznych (partiokracji) itd."1.

\section{Przyczyny powstania i upadku totalitaryzmu}

Trwające dziesiątki lat panowanie totalitaryzmu, który gardził politycznymi mechanizmami demokracji ${ }^{2}$, było rezultatem tej sytuacji $i$ innych uwarunkowań, np. związanych $\mathrm{z}$ warunkami życia w XX wieku w wielu krajach. Ustanawiał on swoją władzę (drogą zamachu stanu, puczu lub narzucenia $\mathrm{z}$ ze-

\footnotetext{
${ }^{1}$ Patrz: hasło demokracja [w:] Encyklopedia socjologii pod red. Z. Bokszańskiego i innych. Oficyna Naukowa, Warszawa 1998, t. 1, s. 123.

${ }^{2}$ Totalitaryzm oznacza ustrój polityczny, w którym wszelkie zachowania społeczne kontrolowane są przez arbitralną władzę, realizującą zamkniętą i niepodlegającą ocenie wizję ideologiczną. Patrz: Slownik polityki pod. red. M. Bańkowicza. WP, Warszawa 1999, s. 252.
} 
wnątrz), starając się tworzyć pozory, że władza ta została powołana wolą ludu. Zależało mu na legitymizacji, chociażby miała to być legitymizacja fikcyjna ${ }^{3}$. $\mathrm{Z}$ pożytkiem dla siebie ustrój totalitarny posługiwał się pojęciem mas, których przecież nikt nie liczy, ponadto $\mathrm{z}$ masami nie ma konieczności dyskutowania. Masy, w tym sensie, są wygodnym przeciwieństwem wszelkiej zindywidualizowanej zbiorowości. Pragnienia i żądania mas formułowane były przez funkcjonariuszy rządzącej elity i podawane tymże masom jako ich wola - jako wola ludu ${ }^{4}$.

Oczywiście, że pojęcie mas może mieć też inny sens, np. zdaniem Ortegi Gasseta, nie musi to być tłum złożony z indywidualnych jednostek, ale może odnosić się do masowego członka społeczeństwa, który odgrywa ważną rolę w demokracji. „Masy stanowią ci wszyscy, którzy nie przypisują sobie jakichś szczególnych wartości - w dobrym tego słowa znaczeniu czy w złym - lecz czują się »tacy sami jak wszyscy $i$ wcale nad tym nie boleja, przeciwnie, znajdują zadowolenie w tym, że są tacy sami jak inni. Wyobraźmy sobie teraz człowieka skromnego, który próbując dokonać oceny własnej wartości, zadaje sobie pytanie, czy posiada jakieś szczególne zdolności, czy wybija się w jakiejkolwiek dziedzinie życia, po czym ostatecznie dochodzi do wniosku, że niestety żadnych szczególnych zdolności czy zalet nie posiada. Człowiek ten czuje się szary, bezbarwny i skrzywdzony przez los, ale nie czuje się »masąı5

Założenia i praktyka totalitaryzmu prowadziły do całkowitego ubezwłasnowolnienia społeczeństwa, chociaż ogólniejsze spojrzenie pozwala na przyjęcie poglądu, że „Niektóre spośród najgorszych krzywd wyrządzonych ludziom w XX stuleciu popełnionych zostało nie przez reżimy uniwersalistyczne, ale przez władze przywiąane do ideałów wspólnoty organicznej. Jeśli naziści mieli jakikolwiek spójny światopogląd intelektualny, nie wywodził się on $\mathrm{z}$ żadnej odmiany uniwersalizmu. Jego pochodzenia należy szukać $\mathrm{w}$ kontroświeceniu, z jego odrzuceniem idei jakiejkolwiek wspólnej ludzkiej natury i odwoływaniem się do wyjątkowości ludów i do ich indywidualnych historii"'6.

\footnotetext{
${ }^{3} \mathrm{~K}$. Popper dopatrywał się korzeni totalitaryzmu już w myśli starożytnej np. u Platona. Patrz: Spoleczeństwo otwarte i jego wrogowie, T. I i II, Warszawa 1993.

${ }^{4}$ Tego, co naprawdę myślą masy, nie da się ustalić, dopóki pojęcie masy funkcjonuje jako wspólny mianownik przeważającej części społeczeństwa. Powinno się zasięgać opinii poszczególnych ludzi, co nieuchronnie prowadziłoby do zakwestionowania samego istnienia mas.

${ }^{5}$ Według Ortegi Gasseta, cechą charakterystyczną naszych czasów jest panowanie mas, tłumu, nawet $w$ grupach o elitarnych dotychczas tradycjach. Por. Joser Gasset, Bunt mas. Spektrum. W.W.L. Muza S.A., Warszawa 2002, s. 12-13.

${ }^{6}$ Zwraca na to uwage J. Gray, a termin kontroświecenie zaczerpnął od Isaiaha Berlina. Patrz:

Dwie twarze liberalizmu. Przeł. P. Rymarczyk. Alrtheia, Warszawa 2001, s. 191-192.
} 
Ustroje totalitarne okazały się antytezą demokracji, a ustanowione przez ideologie totalitarne formy społecznego i politycznego życia nie mogły być trwałe, mimo pozorów potęgi. Gwałcona przez długie dziesięciolecia natura ludzka - upominając się o swoje prawa - okazała się w końcu silniejsza od fikcji. Ważne jest przy tym spostrzeżenie G. Sartoriego, że ,totalitaryzm stanowił koniec pewnego kontinuum (co prawda nie ciagłego), na którego przeciwnym definiującym końcu znajduje się demokracja (też pojmowana jako typ biegunowy). Wynika $\mathrm{z}$ tego, że nie możemy oczekiwać, aby jakikolwiek konkretny system był »czysto « totalitarny, podobnie jak nie oczekujemy, aby jakakolwiek konkretna demokracja była czystą demokracją"7.

\section{Kryzys oświeceniowej koncepcji „człowieka ogólnego”}

Dla pokonania totalitaryzmu ważna okazała się rola teoretyków demokracji działających niekoniecznie w innych krajach (bo często obok praktyki totalitarnej). Podobnie jak w XVIII i XIX wieku, jako członka i uźytkownika nowoczesnego państwa postulowali oni przez większość XX wieku (jeszcze w zgodzie z myślą oświeceniowa) „człowieka w ogóle", jednostkę abstrakcyjną, która zawsze i wszędzie powinna zachowywać się w ten sam sposób. Nie wynika $z$ tego, że ich wyobrażenie o człowieku było prymitywne i dogmatyczne. Przecież teoretycy i praktycy demokracji liberalnej już dawno wiedzieli, że istoty ludzkie są złożone i rozmaite, że dzieli je przynależność do różnych grup społecznych i narodowych, historia, wykształcenie, inteligencja; że dzielą ludzi także interesy, którym dają wyraz w życiu społecznym. Ideę demokracji liberalnej, która była realizowana od XIX wieku, w dalszym ciagu pojmowano jednak w ten sposób, że nieporównywalnym ze sobą obywatelom proponowało się aktywniejsze uczestnictwo w instytucjach państwa i samorządzie. Dominowało przekonanie (oczekiwanie), że pozwoli to ludziom na przekraczanie, tj. „transcendowanie" osobistych ograniczeń i wzajemnych odrębności, że jako obywatele bedą zawiadywali coraz l'epiej wspólnym dobrem i czuwali nad właściwym funkcjonowaniem całości społeczeństwa.

Przyjmowano, że jeśli obywatel żyjący w społeczeństwie demokratycznym XX wieku może odczuwać, że jest w życiu publicznym obecny, to nie liczą się różnice, lecz równość wobec prawa i zdolność do uczestnictwa w instytucjach. Podobnie jak etyka demokracji XIX-wiecznej, była to $\mathrm{z}$ założenia etyka obywatelska, nader „abstrakcyjna”, co mogło jednak zachęcać ludzi do „wycho-

${ }^{7}$ G. Sartori, Teoria demokracji. Przek1. P. Amsterdamski i D. Grinberg, PWN, Warszawa 1998, s. 250. 
dzenia z siebie", troszczenia się o całość państwa prawa. Na znaczenie rządów prawa w demokracji zwracają uwagę liberałowie: „Przez państwo prawa rozumie się na ogół państwo, w którym władza publiczna poddana jest ogólnym normom (prawu konstytucyjnemu) i może być sprawowana w obrębie, jaki wyznaczaja jej te prawa, przy zachowaniu prawa obywatela do odwoływania się do niezawisłego sędziego, aby ten rozpoznał i przeciwstawił się nadużyciu władzy. Tak rozumiane państwo prawa odzwierciedla klasyczną doktrynę (znaną już w Średniowieczu - uwaga moja - A. B.) o wyższości rządów prawa nad rządami ludzi”8.

\section{Rosnący pluralizm i zmieniający się charakter społeczeństwa demokratycznego}

Demokrację liberalną XX wieku od lat trzydziestych, w różnych miejscach, niekiedy określano już neoliberalizmem. Od tego czasu opracowano koncepcje „państwa dobrobytu” i „państwa ludowego kapitalizmu”, jak i nowe zasady liberalizmu konserwatywnego, akceptującego nierówności, krytycznie ustosunkowanego do państwa socjalnego, niechętnego egalitaryzmowi w życiu politycznym. Liberalizm konserwatywny rozwinął się głównie w Stanach Zjednoczonych ( np. M. Friedman, F.A. Hayek, K.R. Popper). Idee te wywarły duży wpływ na życie polityczne XX wieku. Przeniknęły także do myśli socjalistycznej, ludowej, chrześcijańsko-demokratycznej i nauki społecznej kościoła katolickiego.

Zrodzony $\mathrm{z}$ nowych doświadczeń neoliberalizm, będący jednym $\mathrm{z}$ wyzwań liberalno-demokratycznych, nie stworzył dotychczas szerokiego ruchu politycznego $\mathrm{w}$ rozumieniu partii politycznych. Jest tak może dlatego, że wchodzimy w fazę kryzysu partii politycznych ( $w$ ich obecnym kształcie) w globalizującym się świecie. Rośnie też biurokratyczna władza nad obywatelem, który inaczej się już organizuje. Współczesne państwo demokratyczne składa się coraz częściej z jednostek, które coraz bardziej podkreślają swoją odrębność i domagają się jej uznania w sferze publicznej, co widoczne jest najbardziej w Stanach Zjednoczonych. „Zanika sfera prywatności i luk psychicznych, istniejących przy tradycyjnym modelu życia rodzinnego. Teraz obserwujemy schyłek wpływu rodziny na wychowanie dziecka, które od wczesnych lat jest poddawane działaniu wzorców konformizmu propagowanych przez szkołę, prasę, radio, telewizję. System oficjalny urabia potrzeby, pragnienia jednostki,

\footnotetext{
${ }^{8}$ N. Bobbio, Liberalizm i demokracja. Przekł. P. Bravo. Znak, Kraków 1998, s. 10.
} 
określa skalę pożądanych dóbr i usług oraz wzorce tego, co później ona sama zaczyna odczuwać jako swoje szczęście. System kontroli, najczęściej nieuświadamianej przez jednostkę przenika do wszystkich zakamarków jej prywatnego życia. Steruje nawet jej spontanicznymi reakcjami"'. Pod koniec minionego wieku z coraz większym indywidualizmem szła już w parze silniejsza przynależność do grup, których członkowie czuli się jako mniejszość wewnątrz społeczeństwa (mniejszość etniczna, kulturalna, religijna, seksualna) i domagali się odrębnych praw dla swoich wspólnot. Od wielu lat wobec państwa stawia się żądanie publicznego uznania indywidualnych i grupowych różnic, a obowiązek obywatelski zastępuje poczucie, że to jednostka jest dhużnikiem społeczeństwa. Więź z całościa, poczucie odpowiedzialności za całość stawały się pod koniec wieku coraz bardziej problematyczne. „Dociekania etyczne nie prowadzą do wyłonienia jednego sposobu życia czy systemu wartości, który miałby obowiązywać wszystkich ludzi - czy choćby tylko jednego człowieka. W zamian za to pokazują one, że ludzie mają powody, by żyć na różne sposoby" ${ }^{\text {"10 }}$.

Według badaczy demokracji, od kilkudziesięciu lat dostrzegane są oznaki prawdziwej mutacji, nowego kształtu naszej cywilizacji, którego konsekwencji nie daje się jeszcze przewidzieć. Towarzyszy temu świadomość, że żadna wspólnota polityczna nie może istnieć jedynie na fundamencie różnorodności bądź naturalnej harmonii, każda musi opierać się na jakimś porozumieniu w kwestii tego, co sprawiedliwe - w istocie rzeczy jest ona przez taką umowę ukonstytuowana ${ }^{11}$. Musi to być brane pod uwage $\mathrm{w}$ szukaniu odpowiedzi na pytanie: w jaki sposób można najlepiej pogodzić zjawisko pluralizmu z potrzebą społecznej jedności? Można się zastanawiać nad zaszłymi przemianami demokracji w tej cywilizacji, przemianami nie tyle samych instytucji, ile poczucia demokratycznego, czyli sposobu, w jaki ludzie przeżywają sens i zadania demokracji. W chrześcijańskim podejściu od lat mocno podkreśla się zasadę, że „Współczesne pojęcie demokracji różni się od pojęcia osiemnastowiecznego tym, że podkreśla wage systemu gwarancji dla praw jednostki ludzkiej oraz respektu wobec tego rodzaju praw. To właśnie określamy syntetycznie wyrażeniem »państwo praworządne«. Czyli dla nas współczesnych prawdziwa demokracja nie polega jedynie na samej regule większości, polega ona nie mniej na regule prawa zakorzenionego $\mathrm{w}$ zasadzie sprawiedliwości"12.

\footnotetext{
${ }^{9}$ Patrz: W. Gromczyński, Wstẹp do H. Marcuse, Czlowiek jednowymiarowy. PWN, Warszawa 1991, s. XXV-XXVI. Od niedawna coraz większą rolę w tym procesie oddziaływań odgrywa informacja i manipulacja elektroniczna.

${ }^{10}$ Patrz: J. Gray, Dwie twarze liberalizmu, op. cit., s. 13.

${ }^{11}$ Por.: W.A. Galston, Cele liberalizmu. Przekł. A. Pawelec. Znak, Kraków 1999, s. 162.

${ }^{12} \mathrm{R}$. Buttiglione, Chrześcijanie a demokracja. Ethos. KUL. Lublin 1993, s. 123. Patrz też encyklika Centesimus annus za: A. Błaszczyk, Jan Pawel II (ur. 1920) [w:] Ewolucja państwa. Wybór tekstów, zwłaszcza s. 328-333.
} 


\section{Demokratyczne myślenie i działanie w poszukiwaniu nowego mechanizmu}

Pod koniec minionego wieku, wraz z sukcesem demokracji liberalnej, który może wydawać się względnie trwałym, nastapiło znamienne przesunięcie w jej rozumieniu, sprawiające, że jej koncepcja, a także rzeczywistość zmieniała się i coraz mniej przypominała tę XIX-wieczną. Mimo to, nowy mechanizm demokracji, który będzie różnił się od obecnego, musi wskazać inny i przekształcony sposób przechodzenia od dobra jednostkowego do decyzji wspólnych. Zdaniem Williama Galstona, „W społeczeństwie liberalnym kluczową zasadą pośredniczącą jest zasada liberalnej równości - wola jednakowego traktowania dobra każdej jednostki w procesie wyznaczania polityki społecznej. Nie oznacza to, że owa polityka ma być określona przez sumowanie dobra wszystkich zainteresowanych. Powyższa teza jest negatywna, a nie pozytywna: nie można obronić takiej polityki społecznej, która przyznaje nierówną wagę dobru różnych członków społeczeństwa"13.

U podstaw mechanizmów demokracji kończącego się wieku ważne było już przekonanie, że zmieniające się społeczeństwa liberalne cechuje nieusuwalny pluralizm (jako synonim różnorodności). „Są one areną dla sprzecznych i niewspółmiernych koncepcji ludzkiego dobra. (...) Obok faktu pluralizmu mamy więc dziś do czynienia z zasadniczą zgodą co do pewnych kwestii elementarnych: wszystkie jednostki powinny być traktowane jako wolne i równe; społeczeństwo należy pojmować jako system nieprzymuszonej współpracy; każdej jednostce przysługuje prawo do uczciwego udziału w owocach tej współpracy; na wszystkich obywatelach ciąży obowiązek wspierania i ochrony instytucji, które ucieleśniają wspólną koncepcję sprawiedliwych zasad"14.

$\mathrm{W}$ ostatnich dziesięcioleciach, gdy pojawiło się najwięcej obaw związanych z zataczającą coraz szersze kręgi emancypacja ludu (używając starego języka), zwiększyła się ekspansja demokracji liberalnej ${ }^{15}$. W dalszym ciągu lud był traktowany nieufnie, ale już bez większych obaw, że będzie sięgał po władzę. Słowo „demokracja” zwiększało swoje znaczenie i było coraz bardziej cenione $\mathrm{w}$ narodach naszej cywilizacji. W roli barbarzyńcy widziano coraz częściej przeciwnika demokracji. „Centralnym zagadnieniem dla współczesnego liberalizmu jest kwestia dystrybucji, to znaczy sposób rozdziału uprawnień,

\footnotetext{
${ }^{13} \mathrm{~W}$ tym rozumieniu liberalna koncepcja dobra uzasadnia dwa kluczowe elementy liberalnej filozofii politycznej: teorię publicznych celów oraz teorię publicznych roszczeń. Patrz też: W. A. Galston, Cele liberalizmu s. 203-208.

${ }^{14}$ W.A. Galston, Cele liberalizmu, op. cit. s. $159-160$

${ }^{15}$ Najwięcej podejrzliwości wywołały teorie społeczeństwa masowego.
} 
zasobów i możliwości pomiędzy członków wspólnoty liberalnej. (...) Publiczne działania mające na celu ograniczenie rozpiętości dochodów nie podważają (podstawowych wymogów) liberalnej wolności, a raczej stanowią najwłaściwsze urzeczywistnienie wspólnej wiary w równośćpil

Niemniej funkcjonowanie demokracji komplikowało się dalej. $Z$ jednej, strony idea społeczeństwa obywatelskiego pozwalała dalej traktować „lud” jako roztropnie działającego sprzymierzeńca rozumu, zdolnego w konsekwentny sposób bronić zasad wolności, równości i tolerancji. $Z$ drugiej strony, teoretycy społeczeństwa masowego kreślili wizerunek bestii, opisując ulegający popędom, nietolerancyjny, gustujący w przemocy thum. Obok słowa "demokracja" występowało coraz częściej słowo „populizm" i roztrząsano - jak przed wiekami - wszystkie klasyczne wady ustroju, w którym przewagę zdobywa demos - nieprzewidywalny i łasy przecież na pochlebstwa, sprzyjający tym, którzy zręczniej potrafią schlebiać jego namiętnościom. Upowszechniało się też przekonanie wyrażone przez filozofa: „Lud sam musi być moralny i rozumny, by jego wola zasługiwała na urzeczywistnienie. (...) Współczesna psychologia i socjologia wykazały podatność jednostki na wpływ impulsów irracjonalnych. Irracjonalizacja myślenia i działania znacznie się zwiększa, gdy jednostka występuje w ramach kolektywu i z nim się emocjonalnie utożsamia (psychologia thumu)" ${ }^{\text {"17. }}$.

U schyłku XX wieku w społeczeństwach zachodnich zmiany zaszly tak daleko, że nazywane są rewolucją indywidualizmu, a John Gray w tym procesie dostrzegł, że ludzie hołdujący już odmiennym sposobom życia nie muszą wcale nie zgadzać się ze sobą. Mogą się po prostu od siebie różnić. „Z punktu widzenia idei modus vivendi żaden sposób życia nie może być najlepszy dla wszystkich. Ludzkie dobro jest zbyt różnorodne, aby mogło zostać urzeczywistnione w indywidualnym życiu jakiegokolwiek człowieka. Odziedziczony przez nas ideał tolerancji niechętnie przyznaje, iż istnieje wiele sposobów życia"18. Rozumowanie to ma wyjaśniać zanik „człowieka ogólnego” przejętego ogólnym dobrem, zanik etyki uniwersalistycznej, którą demokracja miałaby chronić. Zapewne to też wywoływało niepokój Józefa Tischnera, gdy pisał o pierwszych latach odzyskanej polskiej demokracji w książce Nieszczęsny dar wolności: „Może się mylę, ale często - bardzo często widzę, jak nasz lęk przed wolnością staje się większy niż lęk przed przemocą" ${ }^{319}$. Sławny teolog widział w tym pro-

\footnotetext{
${ }^{16}$ W.A. Galston, Cele liberalizmu, op. cit., s. 160-161.

${ }^{17}$ Patrz: B. Eagowski, Liberalna kontrrewolucja. Centrum A. Smitha, Warszawa 1994, s. 73.

${ }^{18}$ Idea modus vivendi wzięta od Hobbesa i rozwinięta przez Graya głosi, iż istnieje wiele sposobów życia - w tym także i takie, które trzeba wynaleźć - w których ludzie moga się spełnić, u jej podstaw leży pluralizm wartości.

${ }^{19}$ Por. J. Tischner, Nieszczęsny dar wolności. Znak, Kraków 1993, s. 7-8.
} 
cesie chęć „ucieczki od wolności”, która w wielu społeczeństwach w przeszłości oznaczała ucieczkę w tłum, ucieczkę we wspólnotę, w kolektywizm, ale od kilkudziesięciu lat wolność $w$ demokracji liberalnej stawała się coraz częściej ucieczką w radykalny indywidualizm, tj. w osobny (własny) świat człowieka. Oznaczało to odchodzenie od tradycyjnej definicji obywatela, bo nowym obywatelem staje się powszechnie jednostka - zdaniem Galstona - o coraz to nowych oczekiwaniach. „Ruch praw obywatelskich wywołał falę nowych roszczeń wysuwanych przez uprzednio zmarginalizowane grupy, określające się za pomocą kryterium płci, orientacji seksualnej, rasy i przynależności etnicznej, pochodzenia narodowego, klasy, wieku, kondycji fizycznej, głębokich przekonań moralnych i religii. Głównym tematem polityki społecznej stało się uprawomocnienie odmienności”20.

\section{Problemy demokracji w procesach globalizacji}

Kryzys norm społecznych w ostatniej ćwierci XX wieku wynikał już z procesów globalizacji, z tego, że normy indywidualne stały się nieporównywalne. Te normy prywatne przestały być społecznymi, prowadząc do konsekwencji publicznych. Ludzie coraz częściej kwestionowali większość ustalonych tradycją reguł funkcjonowania wspólnoty. Wzmacniało to już zachowania egoistyczne, nierespektujące norm dotychczasowych, coraz częściej utożsamiano demokrację z całkowitą swobodą indywidualnych poczynań, gwarantujących osobisty sukces. „Społeczeństwo liberalne pojmuje zasadniczo dobro jako możliwość, a nie jako egzekwowany przymusem rozkaz. Jego celem jest to, by każdy obywatel miał zapewniony uczciwy dostęp do dobra (bądź do środków prowadzących do tego celu) - co obejmuje również wewnętrzne predyspozycje rozwinięte na tyle, by jednostka mogła prowadzić godne życie",2! . W złożonej rzeczywistości cywilizacyjnej powstało pytanie: czy uda się przekształcić tę mieszaninę postaw ludzkich $\mathrm{w}$ laboratorium demokracji, respektującej potrzebne normy?

Problem jest w tym, że ludzie uciekający od lat w prywatność przyczyniają się do tego, że rynek kontrolowany przez wielkie korporacje wywiera coraz większy wpływ na kulturę obywatelską i dobro publiczne, zniekształca on i dewaluuje idee polityczne $\mathrm{i}$ w coraz większym stopniu uwidacznia niemoc

\footnotetext{
${ }^{20}$ Koncepcja tolerancji, którą cenimy od pokoleń, zaklada, że istnieje jakiš jeden sposób życia, jako najlepszy dla całego gatunku ludzkiego. Por też: W.A. Galston, Cele liberalizmu, op. cit., s. 161.

${ }^{21}$ W.A. Galston, Cele liberalizmu, op: cit., s. 202.
} 
niezależnej polityki państwowej. Pisał o tym N. Chomsky w książce Zysk ponad ludzi. Neoliberalizm a ład globalny, dochodząc do wniosku, że w nadchodzących latach i dziesięcioleciach możemy spodziewać się wielkiego przewrotu. Trudno jednak przewidzieć jego skutki, i nie można oczekiwać - dodaje autor - że przyniesie humanitarne i demokratyczne rozwiązania bez odpowiedniego uczestnictwa w nich ludzi ${ }^{22}$. Wydaje się, że - bardziej niż kiedykolwiek dzięki osiagniętym prawom politycznym i obywatelskim ludzie mają możliwość zwrócenia uwagi na ważne dla siebie potrzeby oraz wpływania na działania rządzących. Reakcje rządów nawet na ostre i rozległe dolegliwości obywateli często zależą od wywieranych nań nacisków, a pod tym względem ogromna rola przypada $w$ udziale narzędziom realizacji praw politycznych (głosowaniu, publicznej krytyce, protestom itd.). To coraz ważniejsza część „instrumentalnej" roli demokracji i swobód politycznych.

W minionym wieku przyjęło się uważać, że liczne oczekiwania najlepiej spełnia społeczeństwo liberalne. Choć liberalizm ogranicza pewne style życia, to $\mathrm{z}$ perspektywy historycznej społeczeństwa liberalne, czerpiąc $\mathrm{z}$ różnych ludzkich talentów i cnót, zbliżyły się najbardziej do ideału uniwersalności. Rozwój wybitnych zdolności od dawna nie napotykał w tym systemie na większe przeszkody materialne i polityczne, a rozwojowi zwyczajnych zdolności służy powszechny system edukacji. „Są ważne racje, byśmy cenili udział w naszym życiu swobody wypowiedzi i działania, a ponieważ ludzie są istotami społecznymi, podobnie ważne jest, by mogli bez żadnych zewnętrznych ograniczeń uczestniczyć w życiu politycznym. Znaczenie politycznych wolności i praw obywatelskich wynika także z tego, że dla formowania się naszych wartości bardzo ważne jest, aby dokonywało się ono w warunkach otwartej komunikacji i argumentacji, a po to, byśmy mogli publicznie dawać wyraz cenionym przez nas wartościom, potrzebna jest swoboda słowa i wolne wybory" ${ }^{\prime 23}$. Dodajmy, że trzeba jeszcze chcieć korzystać pełniej z istniejacych możliwości, na co zwraca uwage Allan Bloom w sceptycznej opinii o młodym pokoleniu amerykańskim z lat dziewięćdziesiątych: „Braki wykształcenia powodują że studenci szukają oświecenia tam, gdzie jest ono łatwo dostępne, nie potrafiąc odróżnić podniosłości od intelektualnej tandety, mądrości od propagandy"24.

\footnotetext{
${ }^{22}$ Por. N. Chomsky, Zysk ponad ludzi. Neoliberalizm a ład globalny. Przekł. M. Zuber. Wyd. Sląskie, Wrocław 2000 oraz J. Rifkin, Koniec pracy. Schyłek siły roboczej na świecie i początek ery postrynkowej. Wyd. Dolnoślaskie, Wrocław 2001.

${ }^{23}$ Patrz: W.A. Galston, Cele liberalizmu, op. cit., s. 214.

${ }^{24} \mathrm{~A}$. Bloom wini za to amerykańskie szkolnictwo wyższe, które, jak pisze: „zawiodło demokrację i zubożyło dusze dzisiejszych studentów”. Patrz: A. Bloom, Umysł zamknięty. Wyd. polskie 1997, s. 72.
} 
Filozof i socjolog Max Scheler (1874-1928) jeszcze w początkach XX wieku, oceniając krytycznie demokrację, twierdził, że trzeba przebudować jej mechanizm. Miał też pesymistyczny pogląd na współczesne społeczeństwo industrialne, które uważał za rozkład prawdziwych wartości. Podobny wniosek w minionym wieku wyciagali Geatano Mosca, Roberto Michels, Vilfredo Pareto, Robert Dahl i wielu innych znanych badaczy. Także wcześniej była już tradycja takiego myślenia. W jednej sprawie wszyscy są zgodni, że mechanizmy władzy podporządkowane są zawsze zasadzie małej liczby ${ }^{25}$. Michels, badając rolę przywódców politycznych w kształtowaniu dążeń i aspiracji oraz w mobilizowaniu poparcia społecznego dla inicjatyw partii, doszedł do wniosku, że wszystkie organizacje mają tendencje oligarchiczne i tezę tę sformułował jako „spiżowe prawo oligarchii”, które mówi, że „organizacja rodzi dominację wybranych nad wyborcami, mandatariuszy nad tymi, którzy mandatu udzielaja, delegatów nad delegującymi: kto mówi o organizacjach, mówi o oligarchii". Zdaniem Michelsa w miarę rozwoju i biurokratyzacji partii politycznej jest ona coraz silniej zdominowana przez urzędników zobowiązanych do osiagania wewnętrznych celów organizacji oraz przez intelektualistów z klasy średniej, którzy realizują własne cele, różniące się zwykle od celów szeregowych członków partii. Zauważył też proces zburżuazyjnienia wewnątrz partii, w miarę jak przywódcy klasy robotniczej w rezultacie ruchliwości społecznej stawali się członkami klasy średniej i czuli się mniej zobowiązani do realizacji radykalnych zamierzeń. W rezultacie nawet $w$ demokratycznie rządzonych organizacjach dochodzi do podziału na rządzących i rządzonych. Do thumienia inicjatyw ludowych stosuje się często procedury organizacyjne. Michels opowiadał się za bardziej heroicznymi i twardymi formami przywództwa, które nie dałyby się wchłonąć, natomiast Dahl przedstawił pogląd, że nowoczesne państwa przemysłowe są mniej demokratyczne niż poliarchie, czyli zmieniające się koalicje silnych grup interesów. Przez cały wiek XX istniała rozbieżność poglądów w kwestii, jak silny może i powinien być głos ludu w demokratycznym ustroju. Politycy często ignorowali niektóre większości, np. większościową opinię publiczną przeciw karze śmierci.

Według Schelera i innych teoretyków, konkretne poczynania związane są zawsze $z$ konkretnymi decyzjami. Próbując zrozumieć bieg wydarzeń, odwołujemy się często do abstrakcyjnych pojęć, takich jak: rozum, natura, historia czy stosunki produkcji. W istocie jednak nie posuwamy się wtedy zbyt wiele do przodu. Żadnych zjawisk życia zbiorowego nie jesteśmy bowiem w stanie wythumaczyć sobie, odwołując się do bezosobowych idei albo „czynników”. We wszystko uwikłani są zawsze ludzie. Zawsze da o sobie znać zasada matej licz-

${ }^{25}$ Patrz: M. Scheler, Der Formalismus in der Ethik und die materiale Werethik. Berlin 1916. 
by. Można, bowiem przyjąć, że możliwość uczestniczenia publicznego gwałtownie maleje wraz ze wzrostem liczby obywateli ${ }^{26}$. Prowadzi to do wniosku, że anonimowy ogół nie podejmuje nigdy działań na własną rękę. Trzeba przyjać pogląd, że najistotniejszą rolę odgrywają zawsze ci, którzy w imieniu ogółu występują, ci, którzy inspirująjego poczynania i podejmują konkretne decyzje, a są nimi przywódcy. Dzieje świata - twierdził Pareto - przekonują o nieustannej ,cyrkulacji elit”.

W świetle tych spostrzeżeń ważna jest więc jakość przywódców, a dostrzegamy ich w każdej grupie społecznej, w każdej epoce i w każdym ustroju. To oni przemawiają i są oklaskiwani, a także wskazują kierunek. I było tak zawsze, ale współczesne demokracje liberalne wyłaniają swoich przywódców przy aktywnym udziale mediów, które pozwalają lepiej im się przyjrzeć i, co ważne, mogą kreować ich wizerunek. Od wielu lat, dzięki roli telewizji i wchodzącego w nasze życie Internetu, przedstawiciele ścisłej elity politycznej trafiają do każdego domu. Kampanie wyborcze, a zwłaszcza prezydencka, pozwalają zrozumieć, jak istotne znaczenie ma zasada małej liczby. Cała wielka machina mediów obraca się tylko po to, by przesiewać kandydatów i by wyłowić wreszcie tego, który ma zostać przywódcą ${ }^{27}$.

Według liberalisty Galstona, istnienie cnoty i doskonałości politycznych przywódców jest mniej oczywiste aniżeli odpowiednio wysokie oczekiwania od obywateli w ogóle, natomiast cechy przywódcze scharakteryzował on następująco: „Do cnót przywódczych charakterystycznych dla państwa liberalnego należy, po pierwsze, cierpliwość: zdolność do akceptowania i działania w ramach ograniczeń narzuconych przez społeczny pluralizm oraz instytucje konstytucyjne. Po drugie, liberalni przywódcy muszą umieć przeciwdziałać siłom odśrodkowym indywidualistycznego i rozdrobnionego społeczeństwa, wyrabiając w obywatelach poczucie wspólnego celu. Po trzecie, liberalni przywódcy muszą umieć oprzeć się pokusie zdobywania popularności kosztem realizowania nierozsądnych roszczeń opinii publicznej. Po czwarte wreszcie, choć źródłem władzy liberalnych przywódców jest zgoda powszechna, to nie wolno im uzależniać własnej polityki od opinii publicznej. Muszą raczej dysponować umiejętnością zmniejszania dystansu - o ile to możliwe - między publicznymi preferencjami a działaniem rozumnym. Przywódca liberalny, który zlekceważy powszechne odczucia, rychło utraci stanowisko, ale podobny los czeka tego przywódcę, który po prostu potraktuje je jako przepis na własną politykę.

\footnotetext{
${ }^{26}$ Patrz tẹż uwagi na ten temat: R. Piekarski, Czy istnieją cnoty specyficznie polityezne? [w:] Cnoty polityczne - dawniej i obecnie. Moralne źródla polityki pod red. R. Piekarskiego. GTN, Gdańsk 1997, s. 59-87.

${ }^{27}$ Szacunek dla autorytetu, jak przekonywał Dawid Hume w swym eseju $\mathbf{O}$ pierwszych zasadach rządzenia, jest zawsze jedną z głównych sprężyn władzy i demokracja nie robi wyjątków.
} 
Przywódca liberalny usiłuje skłonić obywateli do zaakceptowania rozsądnych poglądów za pomocą perswazji. Granice perswazji muszą wszelako wyznaczać także granice przedsięwzięciom publicznym, gdyż w przeciwnym razie władza przerodzi się w uzurpację,28.

Zmieniała się rola demokratycznego przywódcy w drugiej połowie minionego wieku, niezależnie od pochodzenia. Zmieniały się istotne uwarunkowania mechanizmów władzy, a tym samym i charakter politycznego przywództwa. Społeczeństwa rozrastały się, a demokracja liberalna starała się pogodzić się z prawem wielkiej liczby. Czym innym była władza w odległej przeszłości, rozpościerająca się $\mathrm{w}$ granicach polis, a czym innym jest władza charakterystyczna dla państwa współczesnego i nawet ponadpaństwowa, powstała z grupy państw, np. w Unii Europejskiej. Coraz mniej jest ona widoczna, staje się anonimowa, mimo rosnącej roli mediów, czyli głównym autorytetem pozostaje państwo, ale ludzie działający w jego imieniu znajdują się jakby na drugim planie. Tym bardziej nikt nie wywierał już wpływu tak bardzo bezpośredniego jak antyczny sofista-demagog ${ }^{29}$. W XX wieku - w wielu krajach - władza przekształciła się $\mathrm{w}$ procedurę, a przywódcy rozpływali się w thumie. Wielka liczba.w demokracji liberalnej pomniejsza jednostkę, która jeśli nawet odgrywała rolę szczególna, uzależniona była od masy. W minionym wieku, ale i w całej nowożytności, nie tylko demokratycznej, autorytet (przynajmniej częściowo) kreowały masy i nawet w pewnym sensie one stawały się autorytetem, czego dobrym przykładem było przywództwo kolektywne. Jeśli jednostki nawet odgrywały poważniejszą rolę w takim społeczeństwie, nie była to nigdy rola samoistna. Źródłem władzy - w pewnym sensie - zawsze był ogół.

\section{Biurokracja niebezpieczeństwem dla demokracji}

Współczesne mechanizmy władzy - zdaniem wielu badaczy - podlegają nie tylko prawom matych, ale i wielkich liczb. O charakterze politycznego przywództwa w XX wieku decydował przede wszystkim fakt, iż działalność nowoczesnego państwa niesłychanie się skomplikowała, dlatego losy demokracji splotły się z losami biurokracji. Współcżeśni „doradcy ludu” to specjaliści wielka armia urzędników, którzy muszą obsługiwać skomplikowaną maszynerię państwa. Działaja anonimowo, są niewidoczni, ale to nie zmniejsza przecież ich rangi.

\footnotetext{
${ }^{28}$ W.A. Galston, Cele liberalizmu, op. cit., s. 247-248.

${ }^{29}$ Czyli że dzisiejszy lud ma wielu doradców i często nie widzi ich oblicza.
} 
Nowoczesne państwo - pisał w pierwszym ćwierćwieczu XX wieku Max Weber - nie może stworzyć administracji niezbiurokratyzowanej. Jedyny wybór - pisal - to wybór „między biurokracją i dyletantyzmem”. Taka demokracja - z założenia - oznacza działalność poddaną rygorom rozumu. Jest to wtedy działalność zgodna z pewnymi ogólnymi zasadami kompetencji i fachowości, jako działalność podporządkowana władzy reguł. Ma ona wykluczać arbitralność i chwiejność.

To właśnie biurokracja - jak przekonywał Weber w swojej książce Gospodarka $i$ społeczeństwo ${ }^{30}$ - w największej mierze miała urzeczywistniać zasadę rządów prawa. Miały to być rządy urzędników, reprezentujących z założenia interes prawa, jednocześnie lojalnych wobec państwa, a nie wobec partii, koterii, grup nacisku. Wielkim sukcesem biurokracji - sądził Weber - stało się oddzielenie urzędu publicznego od osoby urzędnika. Urzędnicy są niejako kolektywnym przywódcą ludu. Przygotowują przecież wszystkie ważne decyzje i bez ich opieki lud nie jest sobie w stanie poradzić. Według Webera, biurokracja symbolizuje panowanie legalne, w którym nie liczą się tradycje i charyzma, ale racjonalne, abstrakcyjne reguły, które uzyskały prawomocność $\mathrm{w}$ procedurach wcześniej ustanowionych demokratycznie. Także Gray napisał w tym samym duchu - kilkadziesiąt lat później: „Współczesne ortodoksje traktują rządy prawa jako fakt. Dzięki pomijaniu problemu warunków politycznych, które czynią rządy prawa możliwymi, legalistycznymi, legalistyczny liberalizm (...) mógł przedstawiać prawo jako zupełnie niezależną instytucję. Był w stanie ignorować fakt, że instytucja prawa zawsze uzależniona jest od władzy państwa". W myśleniu liberalnym - dodaje Gray - ignoruje się erozję władzy państwowej, dlatego, że „umożliwia to ukrycie bądź pominięcie konfliktów moralnych i politycznych. Stan anarchii czyni rywalizację praw niemożliwą do uniknięcia, ${ }^{\prime 3}$.

Zwiększenie roli urzędników miało stopniowo zmniejszać niebezpieczeństwa zwiazane $z$ silnymi dotychczas wpływami emocji na życie publiczne, a także pozbawiać znaczenia nadmiernie ambitne jednostki. Niestety, teoretycy społeczeństwa masowego przez cały wiek XX nie potwierdzali pożytków z tak zorganizowanego społeczeństwa. „Duszą tłumu - napisał Gustawe Le Bon nie kieruje bowiem potrzeba wolności, lecz potrzeba uległości. Pragnienie posłuszeństwa każe tłumowi poddać się instynktownie każdemu, kto chce być jego panem,332. Trudno wprawdzie demokratyczny ogół utożsamiać bez żad-

\footnotetext{
${ }^{30}$ Patrz też: M. Weber, Wirtschaft und Gesellschaft. Grundriss der verstehenden Soziologie. Tubingen 1972. Thum. polskie: Gospodarka i spoleczeństwo. Zarys socjologii rozumiejącej. Biblioteka Socjologiczna 2002.

${ }^{31} \mathrm{~J}$. Gray, Dwie twarze liberalizmu op. cit., s. 209.

${ }^{32}$ G. Le Bon, Psychologia tłumu. PWN, Warszawa 1999, s. 9.
} 
nych zastrzeżeń $\mathrm{z}$ tłumem, ale trudno też udawać, że nie ma wielkiego problemu po doświadczeniach totalitaryzmu, nawet po świeżych już, bo z ostatnich lat, w demokratycznej Polsce. Problem widział także Weber, bo państwo początku XX wieku stawało się w istocie państwem mas (Massenstaat), dostrzegał, że już w tym czasie poparcie mas stawało się coraz bardziej potrzebne. Już wcześniejsze, dziewiętnastowieczne partie notabli zmieniały się w partie szukające masowego poparcia. Rósł więc wpływ mas na politykę $e^{33}$, aczkolwiek demokratyzacja nie musiała oznaczać - według Webera - „wzrostu aktywnego udziału rządzących mas", dlatego uważał, że nadchodząca demokracja będzie po prostu "demokracją plebiscytarną". Później, pod koniec wieku, to się już bardzo zmieniało i coraz lepiej widzieliśmy, że demokracja przeżywa kryzys. Wtedy Weber przewidywał, że: „Demokracja plebiscytarna to najważniejszy typ demokracji z przywódcą. Stanowi ona, zgodnie ze swym autentycznym sensem, pewien rodzaj charyzmatycznego panowania, skrywającego się $\mathrm{w}$ formie wywiedzionej $\mathrm{z}$ woli podlegających panowaniu i tylko dzięki niej trwającej prawomocności. (...) Urzędnik z wyboru oznacza wszędzie radykalną reinterpretację pozycji charyzmatycznego przywódcy, który z pana staje się »sługą« podlegających panowaniu"34.

W innej znanej pracy Politik als Beruf (w polskim przekładzie: Polityka jako zawód $i$ powołanie) Weber przekonywat, że współczesne społeczeństwo musi w istocie wybierać pomiędzy „demokracją przywódczą" i „demokracją bez przywódców", czyli władzą zawodowych polityków pozbawionych powołania ${ }^{35}$. Ta druga ewentualność stałaby się faktem, gdyby całą działalność społeczeństwa zdominowała biurokracja. Niewatpliwie wiele $\mathrm{z}$ tego myślenia przejęły totalitaryzmy. Dzisiaj wiemy, że praktyka demokratyczna stara się iść w swoim kierunku, podejmując pewne ryzyko, ale chce być w zgodzie ze swoją naturą. Chociaż obecny kryzys mechanizmów demokracji wzmacnia rolę urzędników, to jednak, zdaniem Galstona: „Liberałowie są skłonni ograniczać demokratyczną władzę po to, aby zmniejszyć ryzyko demokratycznej tyranii" ${ }^{\text {36, }}$ ale są też tacy, którzy skłonni by byli przyjać ryzyko demokratycznej tyranii byle tylko nie ograniczyć demokratycznej władzy. Problem trudnego wyboru drogi dla demokracji dostrzegają też historycy. „Demokracja nie utrwala się tam, gdzie poziom konfliktów społecznych przekracza poziom krytyczny. Wysokość, na której lokuje się owa czerwona kreska, zależy głównie od stanu

\footnotetext{
${ }^{33}$ Ale w późniejszych totalitaryzmach rósł wpływ polityków na masy.

${ }^{34}$ M. Weber, Gospodarka i spoleczeństwo, op. cit., s. 203.

${ }^{35}$ Por. M. Weber, Polityka jako zawód i powolanie. Przeł. P. Egel i M. Wander. NOW, Warszawa 1989, s. 1-38, szczególnie s. 5-9.

${ }^{36}$ W.A. Galston, Cele liberalizmu, op. cit., s. 70.
} 
kultury demokratycznej społeczeństwa" ${ }^{\text {37 }}$. Złożoność sytuacji potwierdzaja spostrzeżenia Daniela Bella z lat dziewięćdziesiątych ubiegłego wieku o wpływie konfliktów społecznych na zachowania niezgodne $\mathrm{z}$ duchem demokracji, a wynikających w części z procesów globalizacji: „Niezależnie od tego, jak przedstawiała się sytuacja w społeczeństwach starożytnych i średniowiecznych, główną cechą zachodnich społeczeństw industrialnych nie jest integracja, lecz separacja. Nie ma już jednego ducha, który ożywiałby wszystkie te wspólnoty. Są one raczej podzielone na odmienne dziedziny, z których każda rządzi się odmiennymi zasadami: sfera polityczna, której legitymizacji dostarcza pojęcie wolnych i równych obywateli, i wreszcie kultura, gdzie coraz bardziej dominuje nieograniczona autoekspresja". W tym układzie - twierdzi dalej Bell możemy wskazać źródła napięć obecnych we współczesnym społeczeństwie: „czy to między strukturą społeczną (przede wszystkim techniczno-gospodarcza, która ma charakter biurokratyczny i hierarchiczny) a polityką oparta formalnie na zasadzie równej partycypacji, czy to między strukturą społeczną zorganizowaną zasadniczo $\mathrm{w}$ kategoriach ról $\mathrm{i}$ specjalizacji a kulturą zainteresowaną rozwojem i realizacją osobowości całego człowieka. W sprzecznościach tych tkwią ukryte źródła wielu konfliktów, znajdujące ideologiczny wyraz w tezach o alienacji, depersonalizacji, w atakach na autorytety itp. ${ }^{.38}$.

\section{Uwagi końcowe}

Nadzieje na lepsze radzenie sobie ze słabościami demokracji liberalnej w Unii Europejskiej mogą być łączone $\mathrm{z}$ wewnętrzną przebudową struktur państwowych, z myśla o potrzebie zwiększenia uczestnictwa obywatelskiego w społecznościach lokalnych.

W ostatnich dekadach XX wieku coraz większą rolę odgrywała informacja jako towar przynoszący wielkie zyski. Zwłaszcza telewizja $w$ swych funkcjach stała się zagrożeniem dla dzisiejszej demokracji. Przestała ona podlegać tradycyjnym kryteriom prawdy i kłamstwa, a zaczęła podporządkowywać się prawom rynku, $z$ ich dążeniem do coraz większych dochodów i do monopolu. Filozofowie oświeceniowi nie mogli przewidzieć świata powstałego w ostatnim pokoleniu, z jego natychmiastową informacja, mediami interaktywnymi, bezlitosnymi komunikatami reklamowymi, telewizyjnymi, kampaniami politycznymi i całą resztą składającą się na kulturę postmodernistyczną. Jednak skoro

\footnotetext{
${ }^{37}$ Patrz: J. Baszkiewicz, Wladza. Pod red. A. Mączaka, W-W-K 1999, s. 139.

${ }^{38}$ D. Bell, Kulturowe sprzeczności kapitalizmu. Thum. S. Amsterdamski, PWN, Warszawa 1994, s. 48.
} 
byli wynalazcami nowożytnej koncepcji demokracji, może warto przywołać założenia, z których wyszli. Żadne nie jest bardziej aktualne niż to, że demokracja oparta jest na publicznym dyskursie, czyli że jego rodzaj i jakość mają szczególne znaczenie. To, że szybciej otrzymujemy większą ilość informacji w bardziej różnorodnych formach i mamy okazję do reagowania na nie, nie oznacza, iż procesy demokratyczne zostały wzbogacone.

Nie można działać skutecznie w cywilizacji demokratycznej, negując jej podstawową zasade $\mathrm{w}$ sferze informacji, to jest odwoływania się do historycznego dziedzictwa i tradycji, także z przyczyn pragmatycznych nie powinno się tego robić. Demokracja liberalna przy wszystkich swych słabościach widocznych przez cały wiek XX w mediach, edukacji, kulturze politycznej dawała jednak możliwość obrony wartości: religii, zasad moralnych, dziedzictwa historycznego i narodowej wspólnoty. Nie można też jej nadwartościowywać i same mechanizmy demokracji sprowadzać do kampanii reklamowej. Mimo że demokracja „cżęsto nie miała racji”, to przecież w ramach tego ustroju (przy równoległych powodzeniach totalitarnych systemów) sukcesy odnosili również mężowie stanu i obozy polityczne stojące na straży niezmiennych - bliskich tradycjonalistom i konserwatystom - wartości, o ile zdołali do swych racji przekonać większość. „Kontynuowana przez cały wiek XX dyskusja nad słabościami i wartościami demokracji nie doprowadziła do sformułowania jej idealnego modelu. Nie dając wyczerpującej listy elementów tego zjawiska, umożliwiła jednak osiagnięcie zgody powszechnej co do koniecznych komponentów kanonu doktryny demokratycznej. Wśród jego podstawowych elementów znalazła się koncepcja ludu jako podmiotu suwerenności i pluralizmu politycznego, zapewniającego różnorodność manifestacji woli ludu. Znalazła się też koncepcja państwa prawnego, zawierająca takie elementy, jak: wymóg klarownej hierarchii aktów prawnych, założenie hierarchicznej struktury aparatu państwowego, zasada, że organy państwa moga działać tylko w granicach dozwolonych i wyraźnie określonych przez prawo, gdy obywatele mogą robić wszystko, czego prawo nie zabrania, gwarancje rządu limitowanego poprzez podział władzy oraz sądową kontrolę konstytucyjności prawa i legalności działań administracji. Wśród elementów koniecznych demokracji znalazło się miejsce na rozwinięcie komponentów formuły Abrahama Lincolna, który głosił, że »demokracja to rządy ludu, dla ludu i przez lud« (Mowa getysburska z 1863 r.). Rządy ludu oznaczać miały w praktyce rządy większości oraz poszanowanie praw mniejszości i poszczególnych jednostek. Rządy dla ludu byłý najczesściej wyjaśniane poprzez ideę społeczeństwa obywatelskiego (civic socjety), w którym państwo jest podporządkowane interesom społecznym. Rządy 
przez lud obejmowały zarówno koncepcję rządu reprezentacyjnego, jak i szerokie wykorzystanie elementów demokracji plebiscytarnej"39.

Wiek XX postawił pod znakiem zapytania sensowność ludzkiego postępu, a sama demokracja liberalna od lat pogrążona jest w kryzysie instytucjonalnym. Dlatego lepiej nazywać ten czas doświadczeniem totalitaryzmu, pomimo zwycięstwa demokracji.

\section{The Sense of Democracy in the Reality of the 20th Century - The Unsolved Dilemmas}

\section{Abstract}

Ideological disputes and certain practices within totalitarian regimes have led to the triumph of democracy in the late 20 th century. The precedent totalitarianism in many countries was mainly a response to the inefficiency of capitalism, as well as a manifestation of disbelief in socialism.

However, the triumphant democracy has proved unable to effectively cope with the new reality of the globalizing world. The mechanisms of democracy having its roots in the Enlightment era are poorly suited to the nature of the new civilization. The Enlightment democracy had postulated a "universal man" - an abstract entity, whose behaviour was to remain unchanged regardless of time and place. It was expected, that the citizens would actively participate in the state institutions and local governments, care about the common welfare and look after the proper functioning of the society as a whole.

Transformations of the rapidly changing world have brought about a crisis of such expectations in contemporary civilization. One of these transformations was the increasingly bureaucratic nature of the governing process.

\footnotetext{
${ }^{39}$ Patrz rozwinieccie hasła demokracja [w:] Encyklopedia socjologii, op. cit., s. 123.
} 